\title{
Description of the first five larval stages of Plesionika narval (Fabricius, 1787) (Crustacea, Decapoda, Pandalidae) obtained under laboratory conditions
}

\author{
JOSÉ MARÍA LANDEIRA ${ }^{1}$, FERNANDO LOZANO-SOLDEVILLA ${ }^{1}$ \\ \& JUAN IGNACIO GONZÁLEZ-GORDILLO ${ }^{2}$ \\ ${ }^{1}$ Departamento de Biología Animal (UDI Ciencias Marinas), Facultad de Biología, Universidad de La Laguna, Campus Anchieta, \\ 38206, La Laguna, Spain.E-mail: jmlandei@ull.es. \\ ${ }^{2}$ Centro Andaluz de Ciencia y Tecnología Marinas, Universidad de Cádiz, c/ República Saharaui s/n, E-11510 Puerto Real (Cádiz), \\ Spain
}

\begin{abstract}
The first five zoeal stages of Plesionika narval were obtained from 15 days of laboratory culture. All larval stages are described and illustrated in detail. Zoeal characters are compared with the previous described larvae of Plesionika acanthonotus and Plesionika edwardsii and with undetermined zoeas of Pandalidae from plankton samples.
\end{abstract}

Key words: Plesionika narval, Pandalidae, larval development, zoea

\section{Introduction}

The pandalid shrimp, Plesionika narval (Fabricius, 1787) is a benthic species inhabiting muddy, sandy, and rocky substrates on the continental shelf, being also found in submarine caves (González 1995). Although the species may occur at depths between $4 \mathrm{~m}$ and $910 \mathrm{~m}$, it is most frequently found between 200 and $400 \mathrm{~m}$ (Crosnier \& Forest 1973; Biscoito 1993; González et al. 1997; Fransen 2006). P. narval shows a wide geographical distribution at low latitudes. In the Indo-West Pacific it has been recorded from the Red Sea and Madagascar to French Polynesia. In the Mediterranean it spreads from the Alborán Sea, western Libya and southern Adriatic Sea, to continental Greece and Marmaris Sea (Fransen 2006). In North-eastern Atlantic it has also been reported throughout the Southwestern Iberian Peninsula, the North-western African coast and in the archipelagos of Azores, Madeira, Salvajes, Canary Islands and Cape Verde, while in South Atlantic it has been identified at St. Helena Island (Udekem D'Acoz 1999). Plesionika narval is valuable as a commercial fishery resource and it is included in the FAO catalogue (Holthuis 1980). At present, this species is being targeted of an important artisanal fishery industry in the Canary Islands, Madeira and Azores.

Currently, the genus Plesionika Bate, 1888 includes more than 80 species (Chan \& Yu 2000), but the larvae of only two species have been described partly based on laboratory rearing. The first stage of Plesionika acanthonotus was described by Bourdillon-Casanova (1960), and the first seven stages of Plesionika edwardsii were described by Landeira et al. (2009). Furthermore, several authors have recognized Plesionika larvae from plankton samples, describing and illustrating them, e.g. Bate (1888), Gurney (1924), Kurian (1956), Bourdillon-Casanova (1960), Williamson (1967a, b), Seridji (1971), Barnich (1996) and dos Santos (1999) (see González-Gordillo et al. 2001, for details). However, according to Landeira et al. (2009), the lack of knowledge on the larval morphology of other pandalid genera such as: Bitias, Chlorotocus, Heterocarpus, which share their geographical distribution with Plesionika, indicate that many planktonic larvae assigned to Plesionika may belong indeed to any of these undescribed genera. 
In order to understand the fluctuations in recruitment and abundance of the $P$. narval populations, it is important to understand the spatial and temporal variability during the pelagic phase. Therefore, description of larval stages is of primary interest. The present study provides detailed descriptions and illustrations of the first five zoeal stages of Plesionika narval based on larvae reared in laboratory, and compares them with the larval morphology of $P$. acanthonotus and P. edwardsii as well as with the putative "Plesionika" larvae reported from several planktonic studies.

\section{Material and methods}

One ovigerous female was collected by local fishermen using bottom traps at $98 \mathrm{~m}$ depth in the south-west of Gran Canaria, Canary Islands $\left(27^{\circ} 45.00^{\prime} \mathrm{N}-15^{\circ} 48.20^{\prime} \mathrm{W}\right)$ and transported to the culture laboratory of "Instituto Canario de Ciencias Marinas, (ICCM)". The female was kept in a 1001 aquarium with filtered natural seawater. Larval hatching occurred within $48 \mathrm{~h}$, and the most active larvae were transferred to a 501 grey cylindrico-conical fibreglass tank for a massive culture with aerated seawater, temperature of $23.4 \pm$ $0.4^{\circ} \mathrm{C}$ and subjected to a natural photoperiod regime ( $11 \mathrm{~h}$ light: $13 \mathrm{~h}$ dark). The female died two days after hatching. Larvae were fed daily on Brachionus plicatilis grown with culture $\mathrm{Selco}^{\mathrm{TM}}$ at a density of 20 rotifers $\mathrm{ml}^{-1}$, during the first two instars. The third instar was fed on a mixture of rotifers (10 rotifers $\left.\mathrm{ml}^{-1}\right)$ and fresh Artemia sp. nauplii (10 nauplii $\mathrm{ml}^{-1}$ ) and the following ones were fed on Artemia sp. metanauplii enriched with

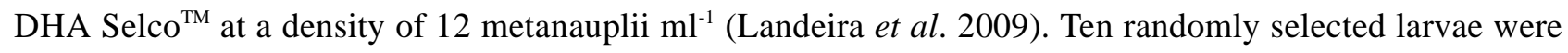
sorted daily and preserved in $80 \%$ ethanol for drawing purposes.

Before drawings, the larval tissues were partially digested with heated lactic acid and stained with Clorazol Black, improving the observation of larval structures (Landeira et al. 2009). The preparations of slides with appendages were made with lactic acid and were not permanent. Drawings were carried out using an interference phase microscope with camera lucida. Larval description and setal counts followed the method proposed by Clark et al. (1998) and setal terminology was the same used for the larval description of Plesionika edwardsii (Landeira et al. 2009) in order to allow comparisons between both species. All figures and descriptions were based on observations of at least 10 specimens belonging to each larval stage. The long plumose setae were drawn truncated and setules from setae were omitted from drawings whenever necessary. Cephalotorax length (CL) was measured from the tip of the rostrum to the posterior cephalotorax margin. The sizes are given as the arithmetic mean $\pm 95 \%$ confidence intervals. Rostrum length/ frontal lobe length ratio (RS/FL) was calculated to show the decrease of rostrum length through the larval development. Specimens of the larval series have been deposited in the "Museo de la Naturaleza y el Hombre (MNH)" in Santa Cruz de Tenerife, Spain (number DL/000734).

\section{Results}

Five zoeal stages were obtained 15 days after hatching. The first zoeal stage is completely described, while only the main differences of the following larval stages are described in detail. Morphology of each larval stage and appendage setation are summarized in Table 1 and the major characteristics defining each larval stage are provided in Table 2.

\section{Larval description}

\section{First zoea}

Cephalotorax (Figures 1A, 2A). Flattened; dorsomedian tubercle on anterior and posterior part of cephalotorax; rostrum smooth, slender, reaching end of antennular exopod and pointed downward; 1 pterygostomian spine, 3 spines along anteroventral margin; compound and sessile eyes. 
TABLE 1. Morphological and meristic features of zoeal stages of Plesionika narval. Setal groups on successive segments are separated by a comma and groups of setae on the same segment, or on different lobes of the same endite, are separated by a plus sign (+). RS, rostral spine; FL, frontal lobe; $6^{\circ}$ and $5^{\circ}$, length of $6^{\circ}$ and $5^{\circ}$ abdominal somites respectively; (-), absent.

\begin{tabular}{|c|c|c|c|c|c|}
\hline Features & $\mathbf{Z ~ I}$ & Z II & Z III & Z IV & $\mathbf{Z V}$ \\
\hline \multicolumn{6}{|l|}{ Cephalotorax } \\
\hline Length (mm) & $0.869 \pm 0.081$ & $0.948 \pm 0.089$ & $0.944 \pm 0.049$ & $0.898 \pm 0.024$ & $0.910 \pm 0.071$ \\
\hline Eyes & sessile & stalked funnel-shaped & stalked funnel-shaped & stalked funnel-shaped & stalked funnel-shaped \\
\hline Ratio RS/FL & 4 & 4 & 3.5 & $>1$ & $>1$ \\
\hline \multicolumn{6}{|l|}{ Antennule } \\
\hline Peduncle & 2 small tubercles & 2 & $1,5,4+6$ & $2+1+4,1+5,5+5$ & $2+(1+1)+6,1+5,5+5$ \\
\hline Endopod & long plumose seta & long plumose seta & long plumose seta & long plumose seta & long plumose seta \\
\hline Exopod & $3+1+1$ & $3+1+1+1$ & $2+1$ & $3+1$ & $1+(2+1)$ \\
\hline \multicolumn{6}{|l|}{ Antenna } \\
\hline Peduncle & 1 & $1 \mathrm{c}$ & $1 \mathrm{c}$ & $1 \mathrm{c}$ & $1 \mathrm{c}$ \\
\hline Endopod & $1+1$ & $1+1$ & 0 & 2 & 0,3 \\
\hline Ratio end/exo & $1 / 2$ & $1 / 2$ & $1 / 2$ & $1 / 2$ & $>1 / 2$ \\
\hline Exopod & $2+1,2,1,1,1,3+1$ & $2+1,2,1,1,1,3+1$ & $5+2,1,1,3+1$ & $14+1+1$ & $14+1+1$ \\
\hline \multicolumn{6}{|l|}{ Maxillule } \\
\hline Coxal endite & $1+5+1$ & $1+5+1$ & $1+5+1$ & $1+5+1$ & $2+2+3+1$ \\
\hline Basial endite & $2+2+1$ & $4+2+1$ & $4+2+1$ & $4+2+1$ & $4+2+1$ \\
\hline Endopod & $(1+1+1)+(1+1)+1$ & $(1+1+1)+(1+1)+1$ & $(1+1+1)+(1+1)+1$ & $(1+1+1)+(1+1)+1$ & $(1+1+1)+(1+1)+1$ \\
\hline Exopod & 0 & 0 & 0 & 0 & 0 \\
\hline \multicolumn{6}{|l|}{ Maxilla } \\
\hline Coxal endite & $9+(1+1+2)$ & $9+(1+3)$ & $10+(1+3)$ & $10+(1+3)$ & $10+(1+3)$ \\
\hline Basial endite & $(3+1)+(3+1)$ & $(3+1)+(3+1)$ & $(3+1)+(3+1)$ & $(3+1)+(3+1)$ & $(3+1)+(3+1)$ \\
\hline Endopod & $(2+1)+(1+1)+1+(1+2)$ & $(2+1)+(1+1)+1+(1+2)$ & $(2+1)+(1+1)+1+(1+2)$ & $(2+1)+(1+1)+1+(1+2)$ & $(2+1)+(1+1)+1+(1+2)$ \\
\hline Exopod & 5 & 5 & 7 & 8 & 8 \\
\hline \multicolumn{6}{|l|}{$\begin{array}{l}\text { First } \\
\text { Maxilliped }\end{array}$} \\
\hline Coxa & $1+1+(1+1)$ & $1+1+(1+1)$ & $1+1+(1+1)$ & $1+1+(1+1)$ & $1+1+(1+1)$ \\
\hline Basis & $(2+1)+(2+1)+3+3$ & $(2+1)+(2+1)+3+3$ & $(2+1)+(2+1)+3+3$ & $\begin{array}{c}(2+1)+(2+1)+ \\
(2+1)+3\end{array}$ & $(2+1)+(2+1)+(2+1)+3$ \\
\hline Endopod & $3,1,2,1+3$ & $3,1,2,1+3$ & $3,1,2,1+3$ & $3,1,2,1+3$ & $3,1,2,1+3$ \\
\hline Exopod & $1+3$ & $1+4$ & $1+4$ & $1+4$ & $1+4$ \\
\hline \multicolumn{6}{|l|}{$\begin{array}{l}\text { Second } \\
\text { Maxilliped }\end{array}$} \\
\hline Coxa & 0 & 0 & 0 & 0 & 0 \\
\hline Basis & $1+2+3+3$ & $1+2+3+3$ & $1+2+3+3$ & $1+2+3+3$ & $1+2+3+3$ \\
\hline Endopod & $3,1,2,1+4$ & $3,1,0,2,1+4$ & $3,1,0,2,1+4$ & $3,1,0,2,1+4$ & $3,1,0,2,1+4$ \\
\hline Exopod & $2+3$ & $2+4$ & $2+4$ & $2+4$ & $2+4$ \\
\hline \multicolumn{6}{|l|}{$\begin{array}{l}\text { Third } \\
\text { Maxilliped }\end{array}$} \\
\hline Coxa & 0 & 0 & 0 & 0 & 0 \\
\hline Basis & $1+1+2$ & $1+1+2$ & $1+1+2$ & $1+1+2$ & $1+1+2$ \\
\hline Endopod & $2,1,2,1+3$ & $2,1,0,2,1+3$ & $2,1,1,2,1+4$ & $2,1,2,1+2,1+4$ & $2,1,2,1+3,1+4$ \\
\hline
\end{tabular}


TABLE 1. (continued)

\begin{tabular}{|c|c|c|c|c|c|}
\hline Features & $\mathrm{Z} \mathrm{I}$ & Z II & Z III & Z IV & $\mathrm{ZV}$ \\
\hline Exopod & $2+3$ & $2+4$ & $2+2+4$ & $2+2+4$ & $2+2+4$ \\
\hline $\begin{array}{l}\text { First } \\
\text { Pereiopod }\end{array}$ & - & - & biramous bud & & \\
\hline Coxa & - & - & - & 0 & 0 \\
\hline Basis & - & - & - & $1+2$ & $1+2$ \\
\hline Endopod & - & - & - & $2,1,0,2,1+2$ & $1+1,1,2,2,1+3$ \\
\hline Exopod & - & - & - & $2+4$ & $2+4$ \\
\hline $\begin{array}{l}\text { Second } \\
\text { Pereiopod }\end{array}$ & - & - & - & biramous bud & biramous bud \\
\hline $\begin{array}{l}\text { Third } \\
\text { Pereiopod }\end{array}$ & - & - & - & - & - \\
\hline \multicolumn{6}{|l|}{ Abdomen } \\
\hline Ratio $6^{\circ} / 5^{\circ}$ & - & - & 3.5 & 3.5 & 3.5 \\
\hline \multicolumn{6}{|l|}{ Uropod } \\
\hline Protopod & - & - & 0 & 0 & 0 \\
\hline Endopod & - & - & 2 & 9 & 7 \\
\hline Exopod & - & - & 6 & $3+9+1$ & $3+9+1$ \\
\hline Telson & $(1+6)+(1+6)$ & $(1+7)+(1+7)$ & $(1+7)+(1+7)$ & $(3+5)+(3+5)$ & $(3+5)+(3+5)$ \\
\hline
\end{tabular}

TABLE 2. Main features and time of appearance to reconnaissance the known larval stages of $P$. narval. Abreviations: end, endopod; exop, exopod; (-), absent.

\begin{tabular}{lcccccc}
\hline Instar & Eyes & $\begin{array}{c}\text { Antenna } \\
\text { segmentation }\end{array}$ & $\begin{array}{c}\text { Antenna ratio } \\
\text { end. / exop. }\end{array}$ & Uropod & $\begin{array}{c}\text { First } \\
\text { Pereiopod }\end{array}$ & $\begin{array}{c}\text { Second } \\
\text { Pereiopod }\end{array}$ \\
\hline ZI & sessile & yes & $1 / 2$ & - & - & - \\
ZII & stalked & yes & $1 / 2$ & - & - & - \\
ZIII & stalked & yes & $1 / 2$ & functional (end. bud) & bud & - \\
ZIV & stalked & no & $1 / 2$ & functional & functional & bud \\
ZV & stalked & no & $>1 / 2$ & functional & functional & bud (longer) \\
\hline
\end{tabular}

Antennule (Figure 2A). Unsegmented peduncle with 2 small tubercles; endopod as long plumose setae; exopod bears terminally 1 plumose seta, 1 spatulate setae and 3 aesthetascs.

Antenna (Figure 4A). Peduncle unsegmented, distally with 1 spiniform seta; endopod unsegmented, with 1 long plumose seta and 1 spiniform seta; exopod broad and distally 6-segmented with 11 marginal plumose setae and 1 simple seta on apex.

Mandible. Asymmetrical, without palp; incisor process with strong armature; molar process with small denticles.

Maxillule (Figure 5A). Coxal endite unilobed with 1 simple seta, 5 denticulate setae, 1 plumose seta and microtrichias; basial endite with 2 plumodenticulate cuspidate setae, 2 plumodenticulate setae, 1 simple seta and microtrichias; endopod unsegmented with 6 setae forming 3 subgroups: the basal one with 1 simple, 1 sparsely and 1 sparsely hardly plumose setae; the following group with 1 sparsely and 1 sparsely hardly plumose setae; and the distal one with only 1 sparsely seta; exopod absent.

Maxilla (Figure 5C). Coxal endite bilobed with 9 plumose setae and 1 sparsely, 1 laterally plumose and 2 plumose setae; basial endite bilobed with 3 sparsely and 1 laterally plumose setae in each; endopod unsegmented and tetralobed with: 2 sparsely and 1 sparsely hardly plumose setae, 1 sparsely and 1 saprsely 
hardly plumose setae, 1 sparsely hardly plumose seta, 1 sparsely hardly plumose and 2 sparsely setae respectively and microtrichias; exopod with 5 long plumose setae and microtrichias.

First maxilliped (Figure 6A). Coxal endite with 1 plumose, 1 plumose, 1 sparsely hardly plumose setae; basial endite with 12 setae forming 4 groups (two groups of 2 sparsely hardly plumose and 1 sparsely setae respectively and two groups of 3 sparsely plumose setae respectively); endopod not extending beyond middle of exopod, 4-segmented, with 3,1,2, sparsely plumose setae and in the distal segment with 1 simple and 3 serrulate setae. Exopod unsegmented bearing 1 subterminal and 3 terminal plumose natatory setae.

Second maxilliped (Figure 6C). Coxal endite without seta; basial endite with $1+2+3+3$ sparsely plumose setae respectively; endopod 4-segmented with 3,1,2 sparsely plumose setae respectively and 1 simple and 4 serrulate setae terminally; exopod unsegmented with 2 subterminal and 3 terminal plumose natatory setae.

Third maxilliped (Figure 7A). Coxal endite without seta; basial endite with $1+1+2$ sparsely plumose setae; endopod 4-segmented, longer than exopod and with 2,1 sparsely plumose setae respectively, 2 serrulate setae and in the distal segment 1 simple and 3 serrulate setae; exopod unsegmented with 2 subterminal and 3 terminal plumose natatory setae.

Pereiopods. Absent.

Abdomen. Five somites without spines or setae.

Pleopods. Absent.

Uropods. Absent.

Telson (Figure 9A). Triangular, broad posteriorly, with 7+7 setae (inner 6 plumoserrulate, outer 1 laterally plumose setae). A row of spinules on the distal margin and around the base of setae (Figure 10).

\section{Second zoea}

Cephalotorax (Figures 1B, 2B). Eyes stalked and funnel-shaped; rostrum shorter, as long as antennular penducle; with 1 pair of supraorbital spines, 1 pair of pterygostomial spines on ventral margin followed by 3 spines along anteroventral margin.

Antennule (Figures 3B). Peduncle unsegmented with 2 terminal plumose setae; exopod bears 1 plumose seta, 1 spatulate seta, 3 aesthetascs and 1 simple seta; otherwise unchanged.

Antenna. Unchanged.

Mandible. Unchanged.

Maxillule (Figure 5B). Basial endite with 4 plumodenticulate cuspidate setae, 2 plumodenticulate setae, 1 simple seta and microtrichia; otherwise unchanged.

Maxilla. Unchanged.

First maxilliped (Figures 6B). Exopod unsegmented bearing 1 subterminal and 4 terminal plumose natatory setae; otherwise unchanged.

Second maxilliped (Figures 6D). Coxal and basial endites without changes; endopod 5-segmented with 11 setae $(3,1,0,2,1+4)$; exopod unsegmented with 2 subterminal and 4 terminal plumose natatory setae.

Third maxilliped (Figures 7B). Coxa without seta; basis unchanged; endopod 5-segmented with $2,1,0,2,1+3$ setae respectively; exopod with 2 subterminal and 4 terminal plumose natatory setae.

Pereiopods. Absent.

Abdomen. Unchanged.

Pleopods. Absent.

Uropods. Absent.

Telson (Figures 9B). Triangular, with $8+8$ setae (inner 7 plumoserrulate, outer 1 laterally plumose seta). 

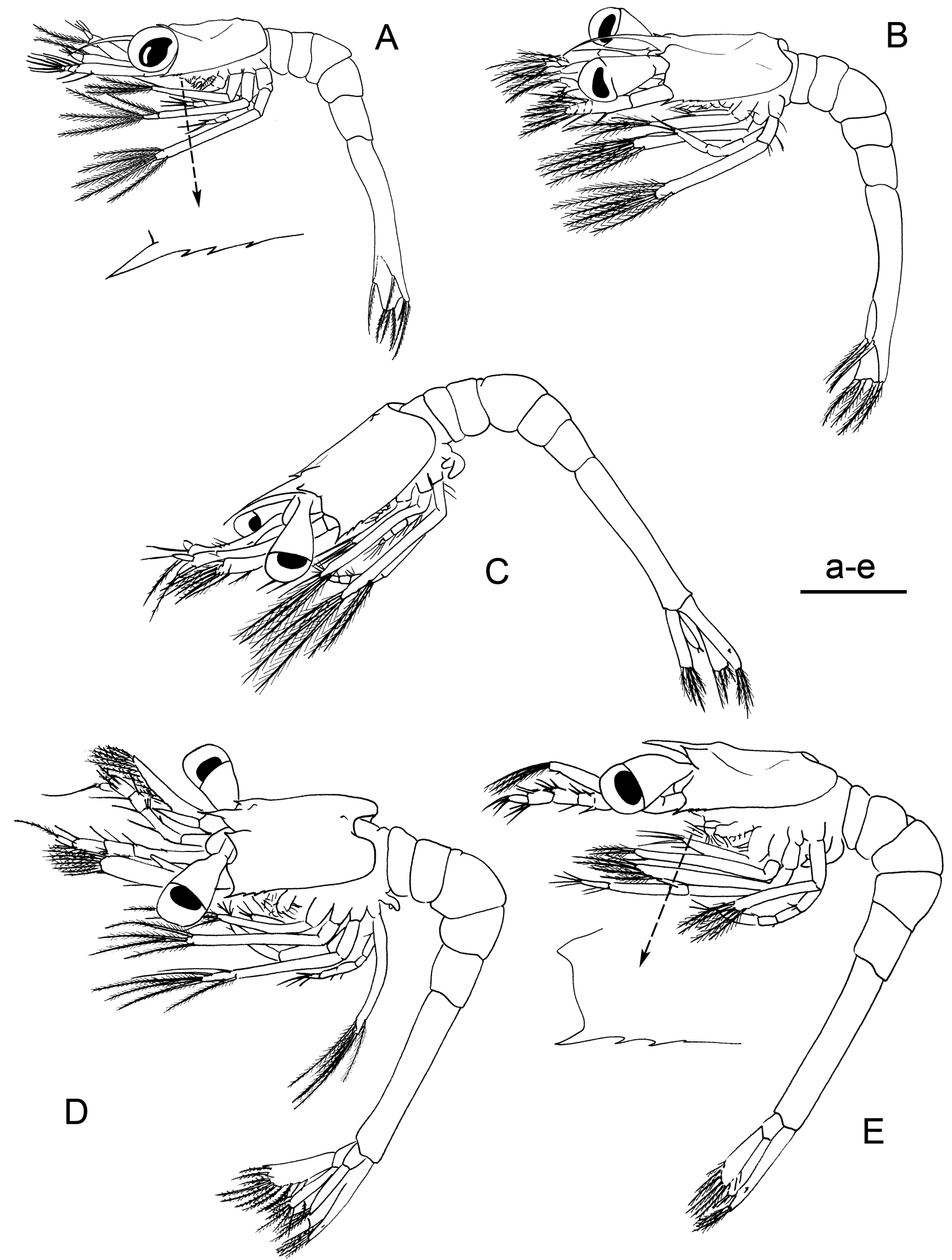

FIGURE 1. Plesionika narval, lateral view: A, zoea I; B, zoea II; C, zoea III; D, zoea IV; E, zoea V. Scale bar: $500 \mu \mathrm{m}$. 


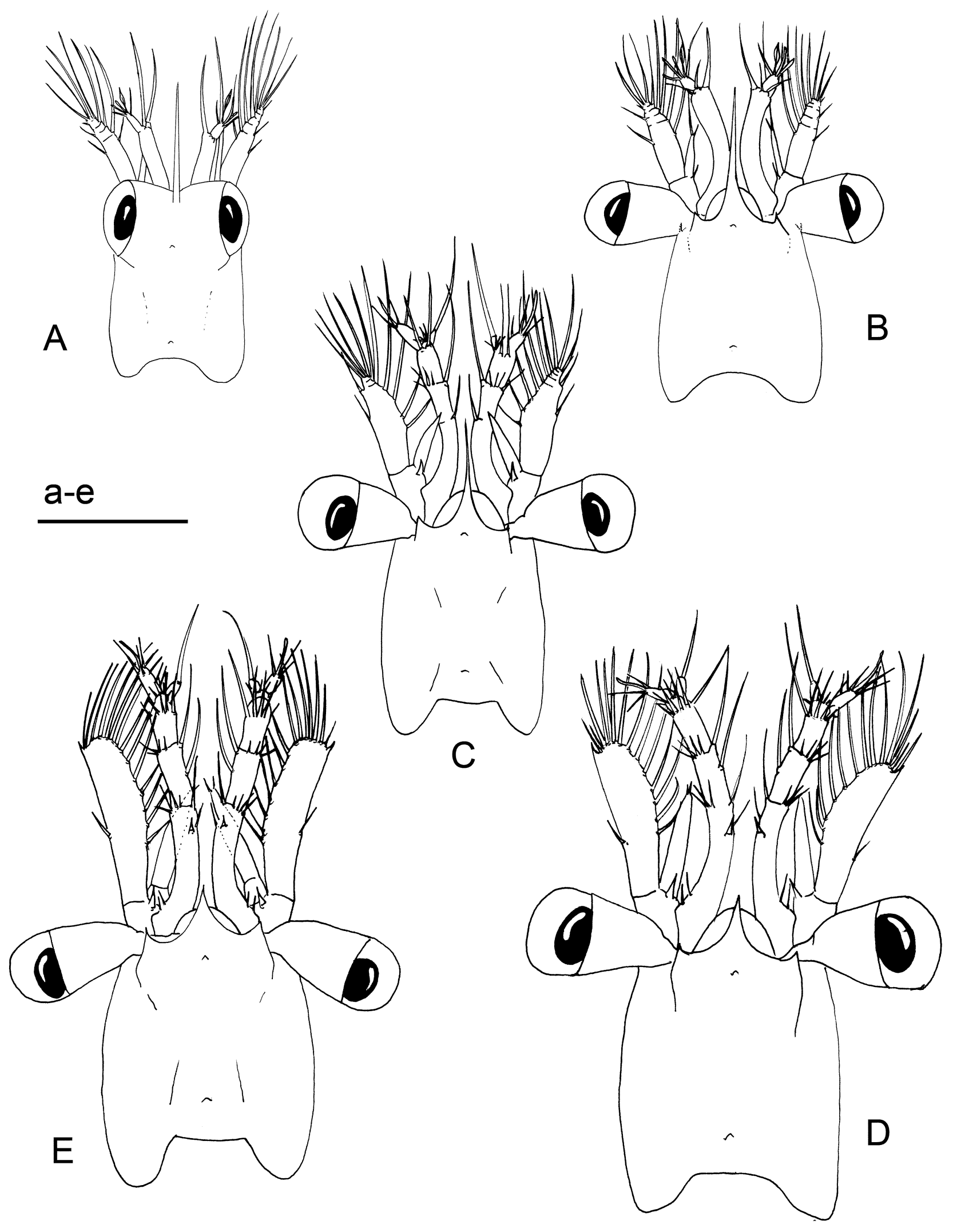

FIGURE 2. Plesionika narval, Cephalotorax dorsal view: A, zoea I; B, zoea II; C, zoea III; D, zoea IV; E, zoea V. Scale bar: $500 \mu \mathrm{m}$. 


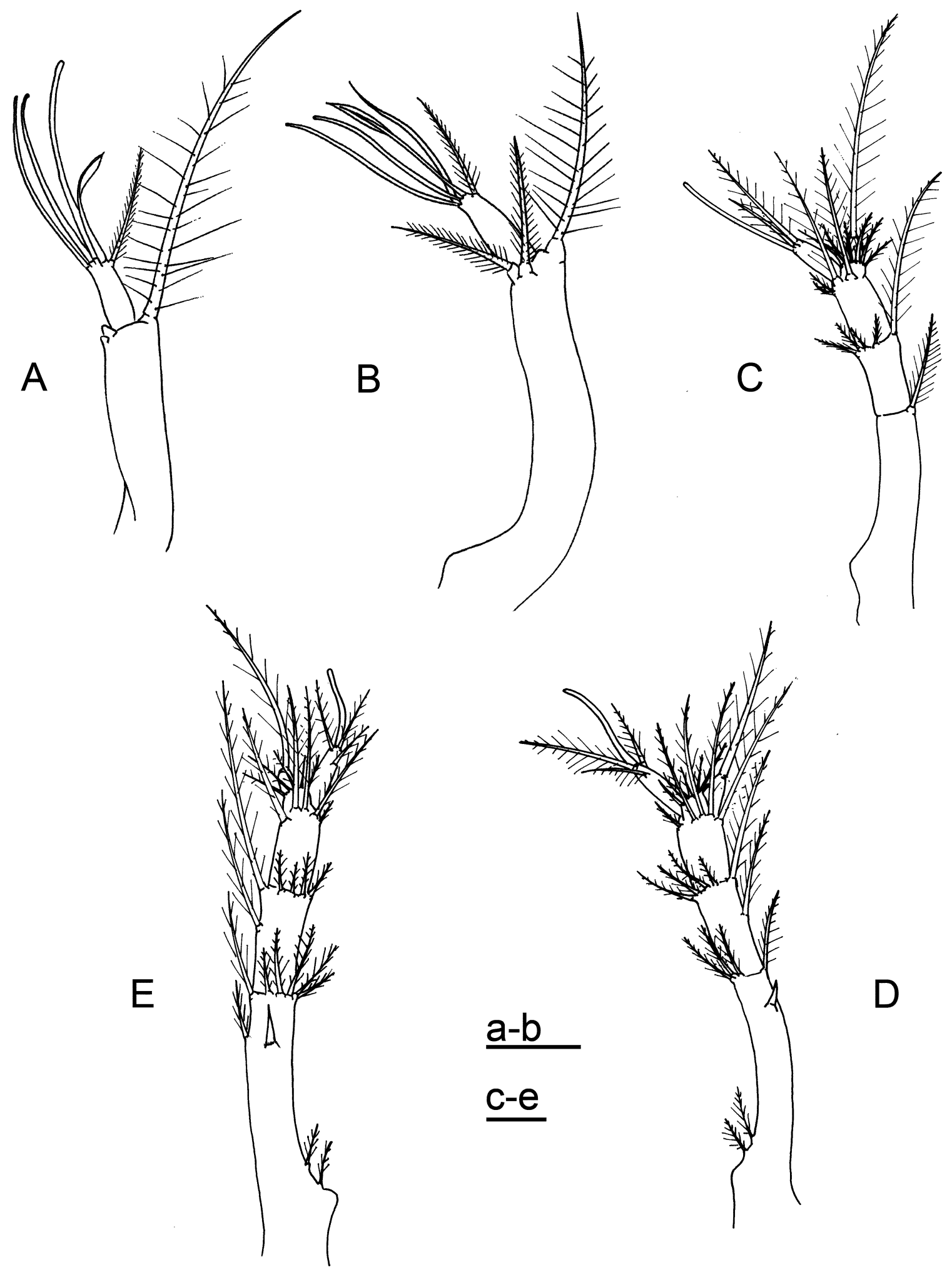

FIGURE 3. Plesionika narval, antennule: A, zoea I; B, zoea II; C, zoea III; D, zoea IV; E, zoea V. Scale bars: $100 \mu$ m. 


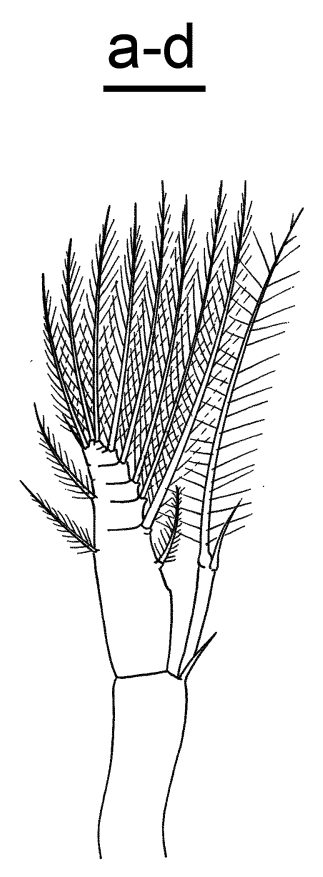

A

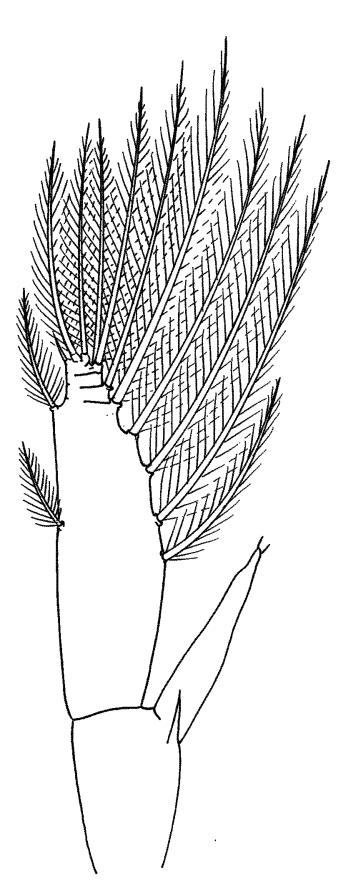

B

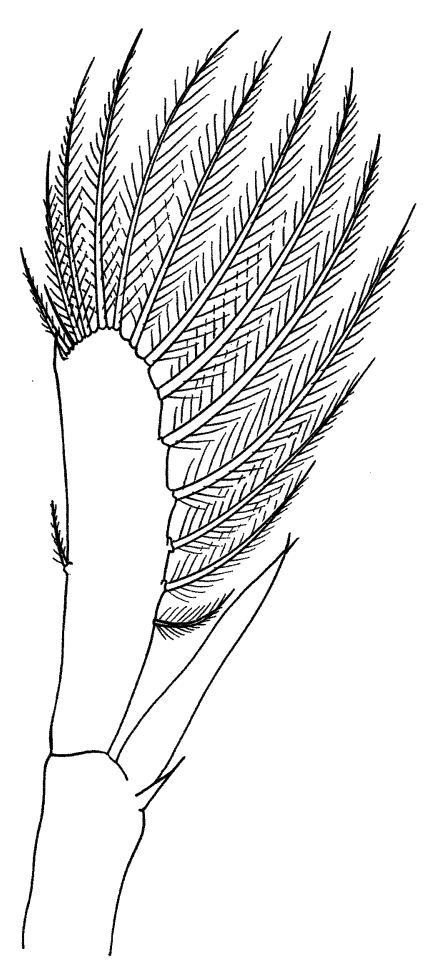

C

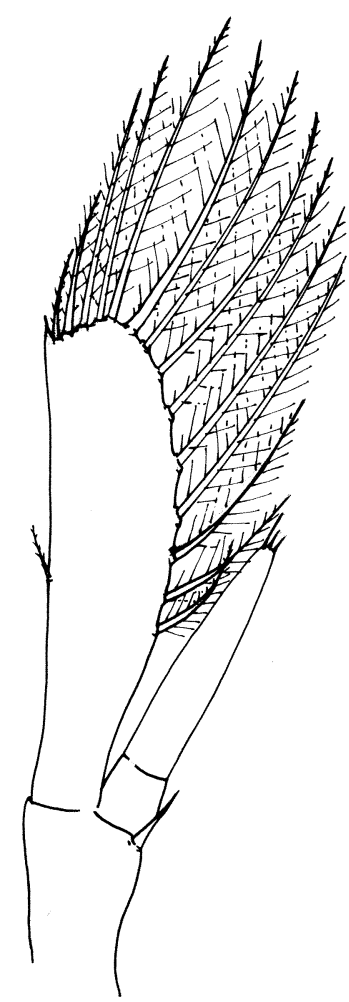

D

FIGURE 4. Plesionika narval, antenna: A, zoea I; B, zoea III; C, zoea IV; D, zoea V. Scale bar: $100 \mu \mathrm{m}$.

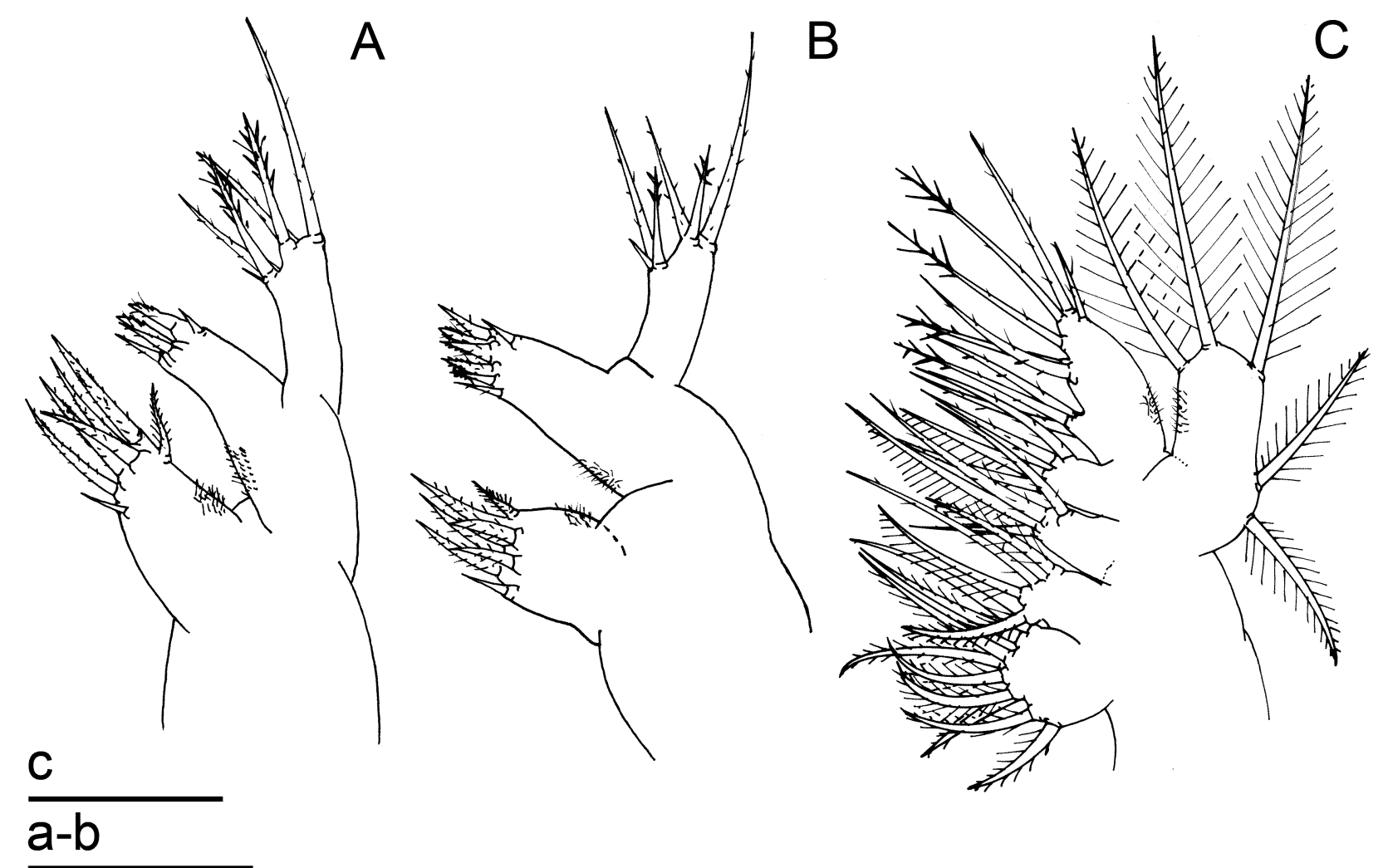

FIGURE 5. Plesionika narval, maxillule: A, zoea I; B, zoea II; maxilla: C, zoea I. Scale bars: $100 \mu \mathrm{m}$. 

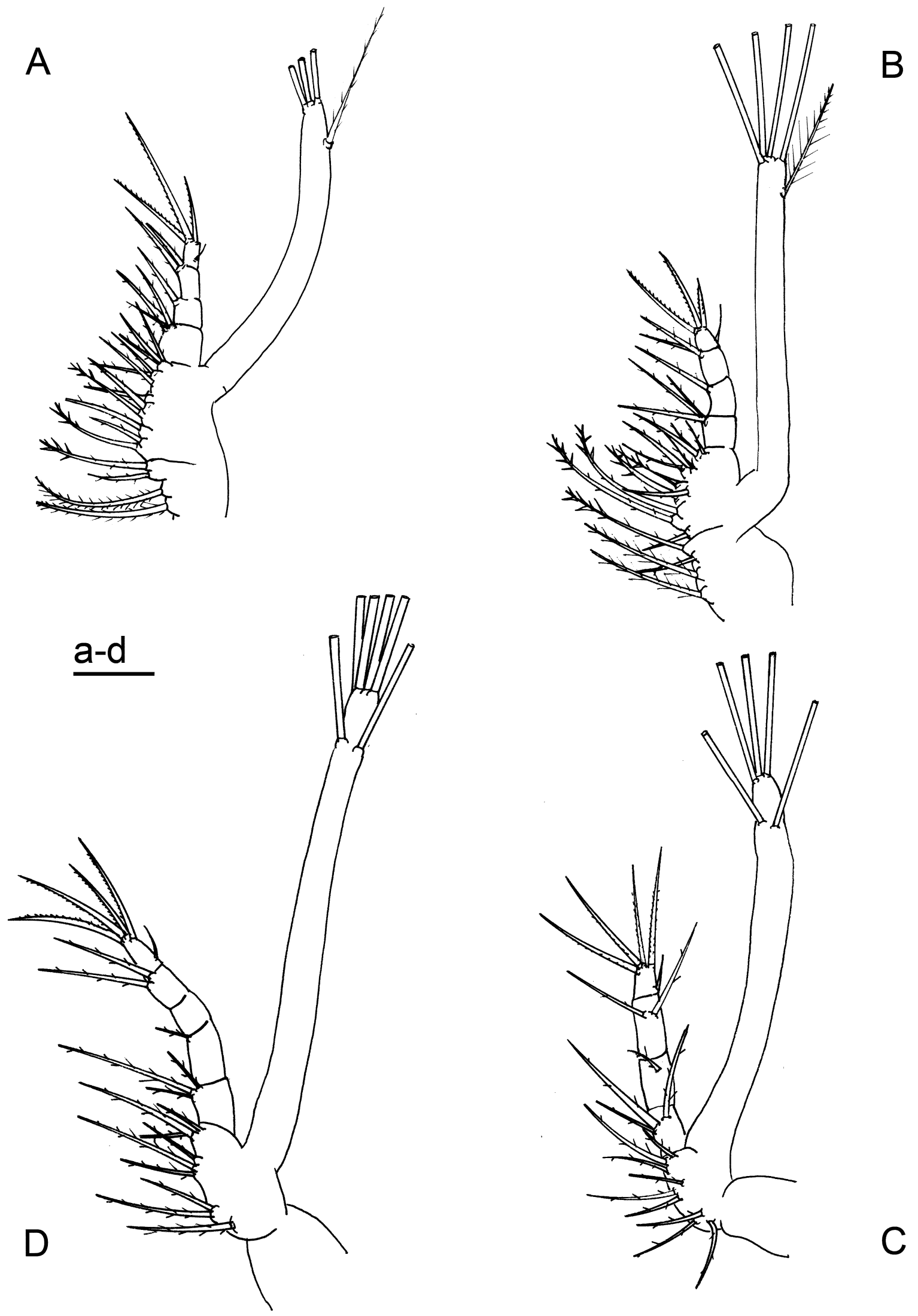

FIGURE 6. Plesionika narval, first maxilliped: A, zoea I; B, zoea II; second maxilliped: C, zoea I; D, zoea II. Scale bar: $100 \mu \mathrm{m}$. 

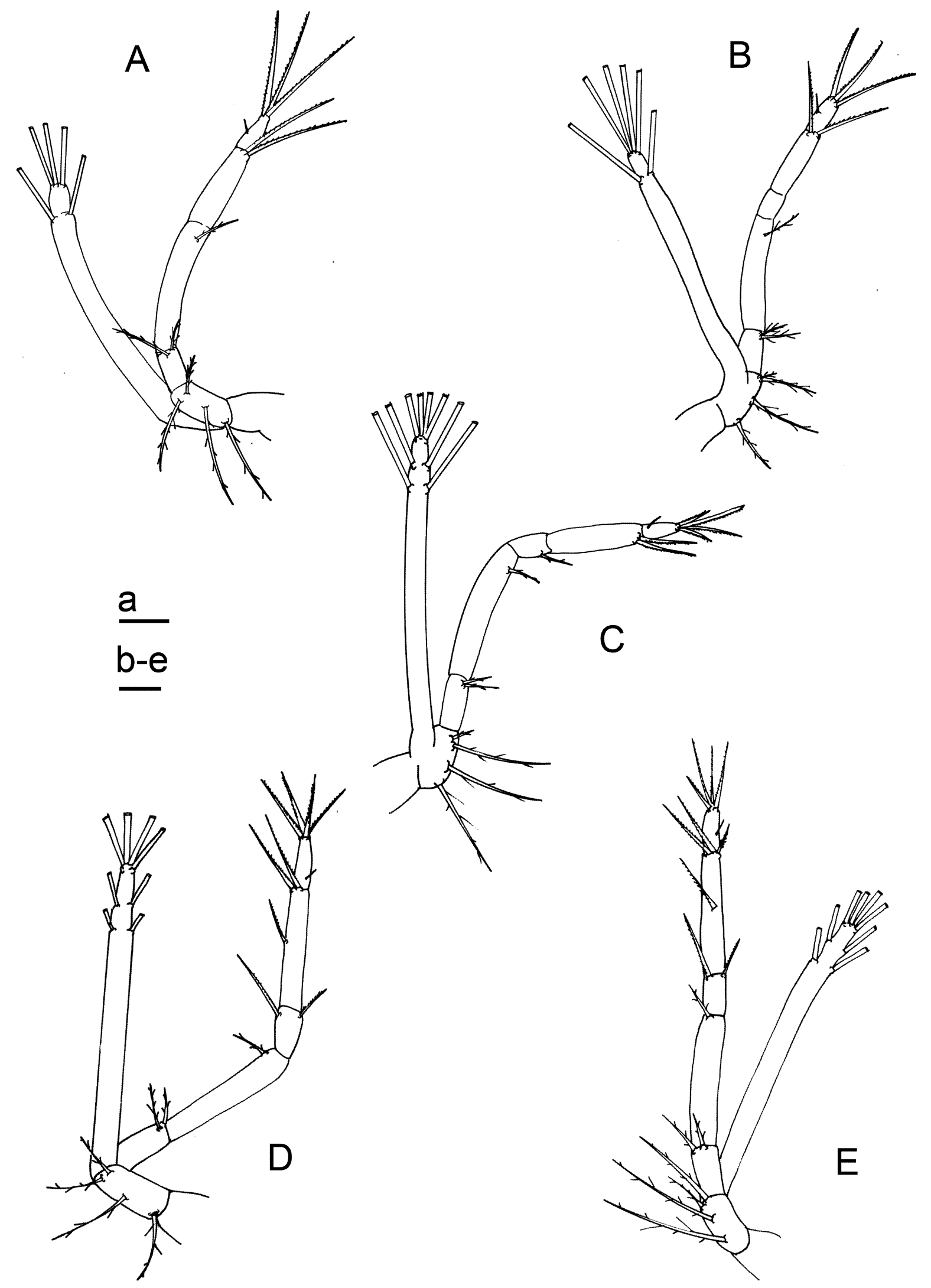

FIGURE 7. Plesionika narval, third maxilliped: A, zoea I; B, zoea II; C, zoea III; D, zoea IV; E, zoea V. Scale bars: 100 $\mu \mathrm{m}$. 


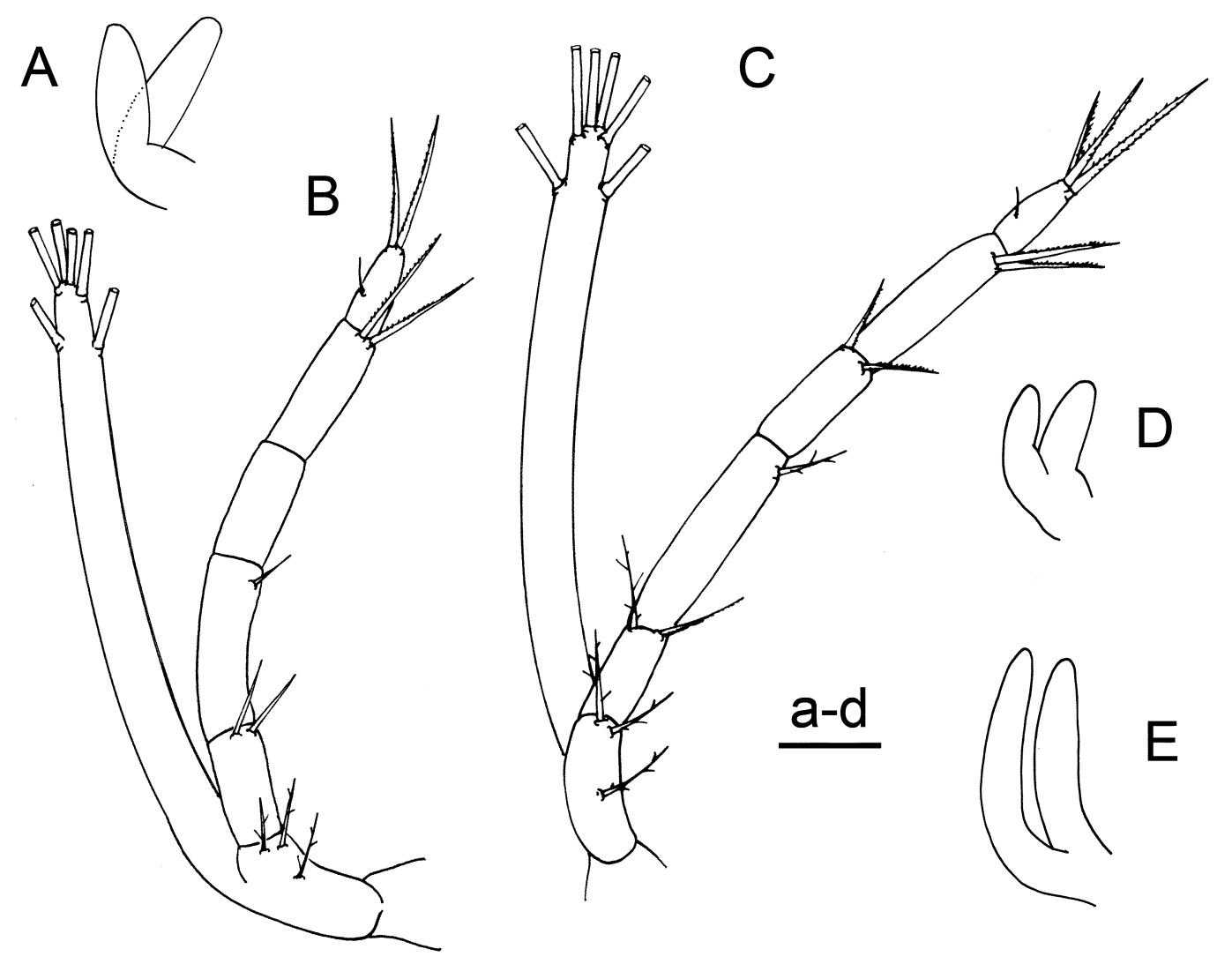

FIGURE 8. Plesionika narval, first pereiopod: A, zoea III; B, zoea IV; C, zoea V; second pereiopod: D, zoea IV; E, zoea V. Scale bar: $100 \mu \mathrm{m}$.

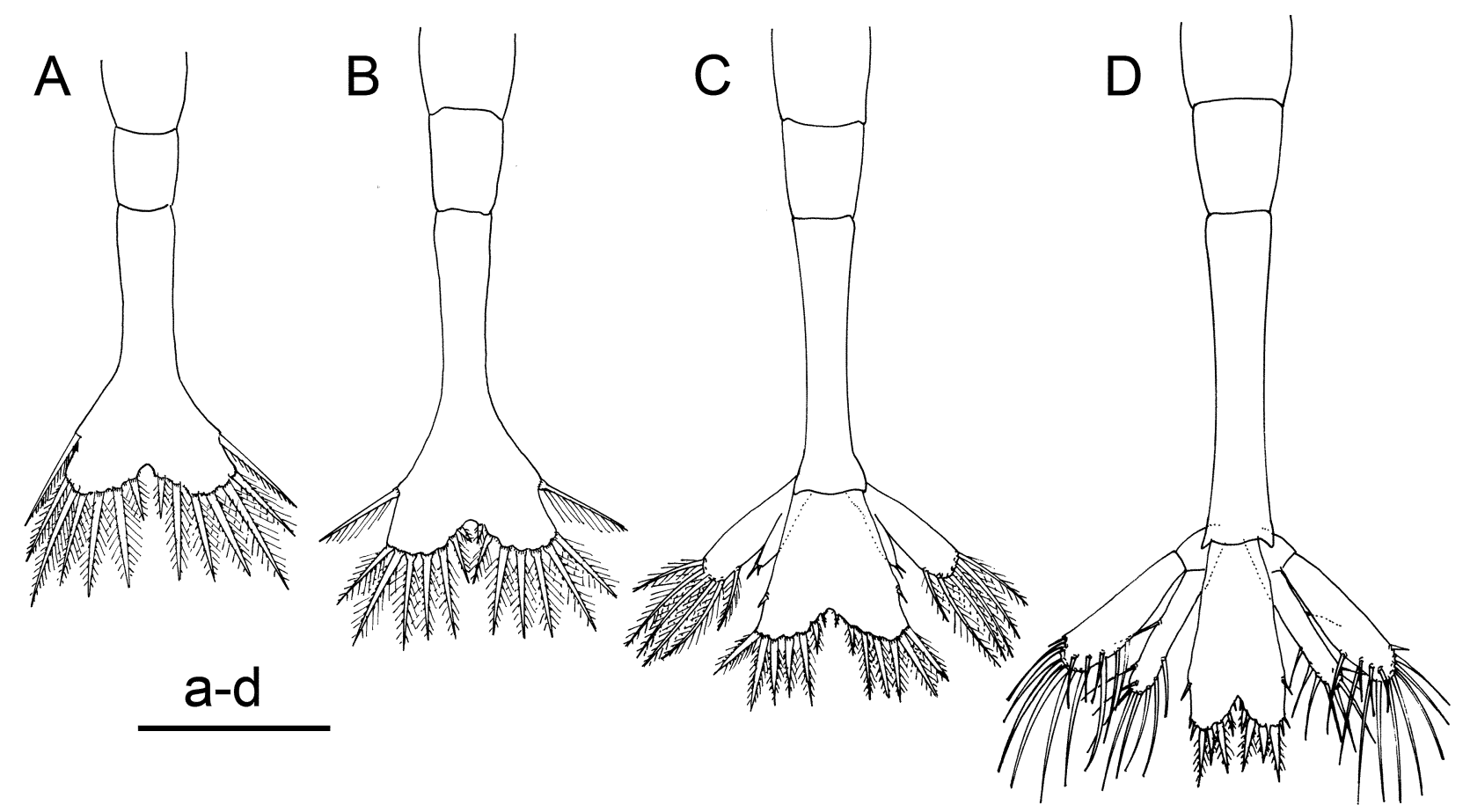

FIGURE 9. Plesionika narval, telson: A, zoea I; B, zoea II; C, zoea III; D, zoea IV. Scale bar: $100 \mu \mathrm{m}$. 


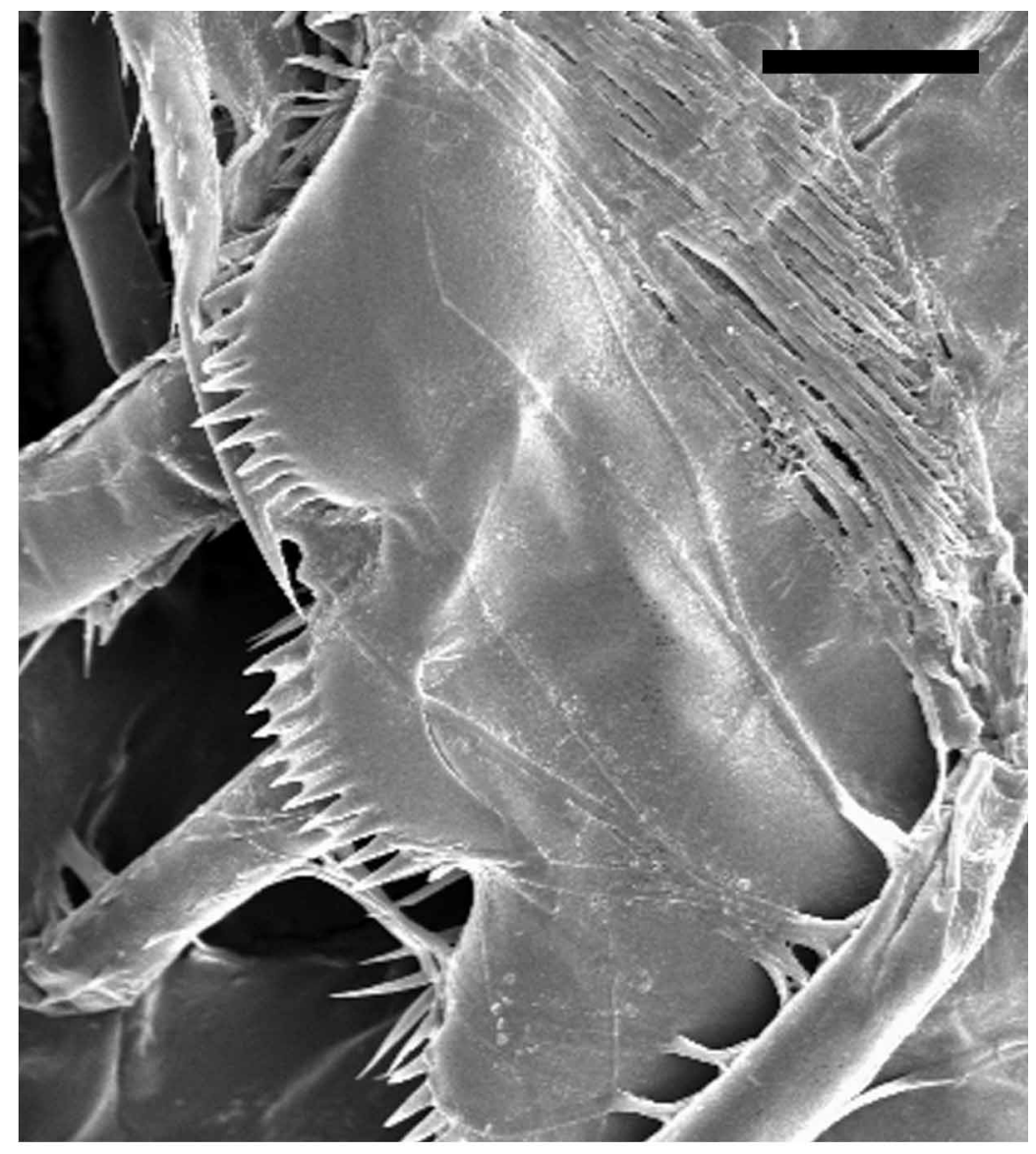

FIGURE 10. Plesionika narval, detail of the distal row of spinules of telson: zoea I. Scale bar: $20 \mu \mathrm{m}$.

\section{Third zoea}

Cephalotorax (Figures 1C, 2C). Rostrum shorter, half of penduncle antennular length; otherwise unchanged.

Antennule (Figures 3C). Peduncle 3-segmented, proximal segment with 1 plumose seta; the following segment with 5 terminal plumose setae; distal segment with 4 plumose setae and 6 plumose setae distributed on distal margin of small process; endopod as long as plumose seta; exopod with 2 plumose setae and 1 aesthetasc.

Antenna (Figure 4B). Peduncle with 1 spiniform seta; endopod unsegmented without seta; exopod 4segmented with 12 marginal plumose setae and 1 simple seta on apex.

Mandible. Unchanged.

Maxillule. Unchanged.

Maxilla. Coxal endite bilobed with 10 and 4 setae respectively; exopod with 7 plumose setae; otherwise unchanged.

First maxilliped. Unchanged.

Second maxilliped. Unchanged.

Third maxilliped (Figures 7C). Endopod 5-segmented with 2,1,1,2,1+4 respectively; exopod with 2+2+4 plumose natatory setae; otherwise unchanged.

First pereiopod (Figures 8A). Biramous bud.

Second pereiopod. Absent.

Pleopods. Absent.

Abdomen. Sixth abdominal somite separated from telson. Otherwise unchanged. 
Uropods (Figure 9C). Biramous; protopod without setae, endopod rudimentary with 2 small plumose setae; exopod well developed with 6 plumose setae.

Telson (Figures 9C). With $8+8$ setae, the outermost pair of setae in subterminal position.

\section{Fourth zoea}

Cephalotorax (Figures 1D, 2D). Rostrum smooth, shorter than zoea III's one, but longer than frontal lobe.

Antennule (Figure 3D). Peduncle 3-segmented; basal segment with 2 proximal plumose setae, 1 strong spiniform seta near the distal edge and 4 distal plumose setae; medial segment with 1 sparsely plumose seta and 5 plumose setae; distal segment with 5 plumose setae and 5 plumose setae distributed on distal margin of a process; endopod as a long plumose setae; exopod with 3 plumose setae and 1 aesthetasc.

Antenna (Figure 4C). Endopod unsegmented, with 2 distal and small simple setae; exopod unsegmented with 14 marginal plumose setae in the inner edge, 1 spiny projection on apex and 1 plumose seta in the outer margin; otherwise unchanged.

Mandible. Unchanged.

Maxillule. Unchanged.

Maxilla. Exopod with 8 long plumose setae and microtrichias; otherwise unchanged.

First maxilliped. Unchanged.

Second maxilliped. Unchanged.

Third maxilliped (Figure 7D). Endopod 5-segmented with se 2,1,2,1+2,1+4 setae, respectively; otherwise unchanged.

First pereiopod (Figure 8B). Coxa without seta; basis with 1+2 sparsely plumose setae; endopod 5segmented with 2 simple, 1 simple, 0, 2 serrulate, and 1 simple plus 2 serrulate setae, respectively; exopod unsegmented with 2 subterminal and 4 terminal plumose natatory setae; exopod as long as endopod.

Second pereiopod (Figure 8D). Biramous bud.

Third pereiopod. Absent.

Abdomen. Unchanged.

Pleopods. Absent.

Uropods (Figure 9D). Protopod without seta; endopod well developed with 9 plumose setae; exopod with 12 plumose setae and 1 simple seta on the outer apex. Endopod and exopod as long as telson.

Telson (Figure 9D). Almost rectangular shaped; 1 pair of lateral simple setae, on the posterior margin with 5 pair of plumoserrulate setae and 2 pair of outer simple setae.

\section{Fifth zoea}

Cephalotorax (Figures 1E, 2E). Unchanged besides size.

Antennule (Figure 3E). Peduncle 3-segmented; basal segment with 2 proximal setae, 1 strong spiniform seta and 1 plumose seta near the distal edge and 6 distal plumose setae; medial segment with 1 plumose seta and 5 plumose setae; distal segment with two groups of 5 plumose setae (the terminal group distributed on distal margin of a process); endopod and exopod unchaged.

Antenna (Figure 4D). Endopod 2-segmented, the basal segment without setae and the terminal one with 3 simple setae; otherwise unchanged.

Mandible. Unchanged.

Maxillule. Coxal endite with 8 setae ( 2 simple, 2 sparsely hardy plumose, 3 plumodenticulate and 1 plumose setae); otherwise unchanged.

Maxilla. Unchanged.

First maxilliped. Unchanged.

Second maxilliped. Unchanged.

Third maxilliped (Figure 7E). Endopod 5-segmented with 2,1,2,1+3,1+4 setae, respectively; otherwise unchanged. 
First pereiopod (Figure 8C). Endopod 5-segmented with 1+1,1,2,2,1+3 setae, respectively; endopod longer than exopod; otherwise unchanged.

Second pereiopod (Figure 8E). Biramous bud, but longer than zoea IV's ones.

Third pereiopod. Absent.

Abdomen. Unchanged.

Pleopods. Absent.

Uropods. Endopod with 10 plumose setae; otherwise unchanged.

Telson. Rectangular shaped; otherwise unchanged.

\section{Discussion}

The larval development of Plesionika narval has not been previously described. The morphology presented herein agrees with the common characters of pandalid larvae: eye peduncle narrowed at base, antennular peduncles strongly concave, well developed rostrum from first stage on, supraorbital spines present and cephalotorax with two dorsal protuberances (Thatje \& Bacardit 2000).

The early zoeal development of P. acanthonotus and P. edwardsii (see Bourdillon Casanova 1960; Landeira et al. 2009) differ from P. narval in several characters. However, the very undetailed description of $P$. acanthonotus does not allow a proper comparison with the other species. Therefore the only recognizable difference is the number of denticles over the ventral cephalotorax margin ( $P$. narval presents 3 denticles; $P$. edwardsii has 2 denticles in zoea I and 0 denticles in the following stages; $P$. acanthonotus lacks denticles). Other interesting features are the absence of 1 exopodal seta in the maxillule of $P$. narval and the presence of 1 distal seta on the peduncle of the antennule in P. acanthonotus. On the other hand, the setation pattern of maxillule, second and third maxillipeds shows differences between P. edwardsii and P. narval. The former species bears 5 setae in the endopod of maxillula, whereas the latter carries 6 setae. Moreover, the coxa of second maxilliped is always naked in P. narval while the first two zoeal stages of $P$. edwardsii show 1 seta. With respect to third maxilliped, $P$. narval bears 2 setae in the proximal segment of endopod and setation $(1+1+2)$ in the basis while $P$. edwardsii presents only 1 seta and $(1+1+1)$ formula.

The characters defining the five larval stage of $P$. narval are summarized in Table 2 . It is provided in such a way it allows easy identification of each stage of this species. Taking into account the pattern emerging from Table 2, we found a small group of specimens that constitute an intermediate form between zoea IV and zoea $\mathrm{V}$. These larvae present typical features of zoea IV (functional uropods present and unsegmented antennal exopods and endopods) but also bear characters of zoea $\mathrm{V}$ stage (second pereiopods and antennal endopods longer). Unfavourable environmental conditions such us unsuitable food supply, low salinities, extreme temperatures and pollution can induce this plasticity phenomenon (Criales \& Anger 1986; Anger 2001). The intra-stage variability has been previously observed in all higher decapod taxa, although particularly more pronounced in the Caridea species with relatively many zoeal instars (Anger 2001). In this respect, the absence of third pereiopods and pleopods in zoea $\mathrm{V}$ of Plesionika narval suggests a long larval series of zoeal stages, but probably shorter than $P$. edwardsii because the first pereiopod appears earlier in $P$. narval than $P$. edwardsii. We agree with Pike \& Williamson (1964) and Landeira et al. (2009), who suggested that the genus Plesionika has a long larval development, probably up to ten zoeal stages.

Regarding the larvae collected in plankton samples, Lebour (1940) suggests that the ones described as Icotopus by Bate (1888), Coutière (1907) and Gurney (1924) could belong to Plesionika. Despite the data provided in the present study, the identity of Icotopus remains unresolved, because these larvae appear to be in more advanced developemental stages than the specimens of $P$. narval described herein. Landeira et al. (2009) considered Icotopus as a pandalid group of a genus with undescribed larval development. In addition, Williamson (1967a, 1967b) reported the occurrence of last stage larvae of Plesionika martia? and Icotopus EM2 which we were not able to confirm either. 
On the other hand, Kurian (1956) and Seridji (1971) described larvae collected in the plankton that look very similar to $P$. narval. Despite its similarities with $P$. narval the poor description and incomplete drawings from the original authors prevented the ascription of these larvae to $P$. narval. Concerning the larvae assigned to Plesionika sp. and Plesionika FSL12 by Barnich (1996) and dos Santos (1999) respectively, they seem very close to $P$. narval, mainly the zoea I specimens. Nevertheless, some differences were found in zoea II and zoea III, when the first and second pereiopod bud appear, respectively, suggesting a shorter larval development. Also, the presence of denticles on the rostrum from zoea IV on, and the presence of one seta on the exopod of the maxillule confirm the differences between them.

Although the genus Plesionika contains more than 80 species, only 3 species have their larval morphology, at least partially described from laboratory reared material. Therefore, further studies must be carried out in order to establish the general pattern of Plesionika larval development.

\section{Acknowledgements}

The authors thank to José Ignacio Santana, José Antonio González and Ignacio José Lozano for providing the ovigerous females and to Daniel Montero and Javier Roo from Instituto Canario de Ciencias Marinas for culture support. This work was partially funded by project PESCPROF1 (Interreg IIIB, MAC/4.2/M12) REDECA (CICYT, CTM2005-07712-C03-01/MAR) and by the Formación de Personal Investigador (FPI) grant to J.M.L. (BES-2005-10960). JIG-G was supported by the Ramón y Cajal Research Program from Spanish Science and Technology Ministry and FEDER.

\section{References}

Anger K. (2001) The Biology of Decapod Crustacean Larvae. Crustacean Issues 14. A. A. Balkema Publishers, Rotterdam. 420 pp.

Barnich, R. (1996) The larvae of the Crustacea Decapoda (Excl. Brachyura) in the plankton of the French Mediterranean coast. $\mathrm{PhD}$ thesis, Göttingen, Cuvillier Verlag. $189 \mathrm{pp}$.

Bate, C.S. (1888) Report of the Crustacea Macrura collected by H.M.S. Callenger during the years 1873-76. Report of the scientific results or the Voyage of H.M.S. Challenger, Zoology, 24, XC+1-942.

Biscoito, M.J. (1993) An account of the shrimps of the family Pandalidae (Crustacea, Decapoda, Caridea) in Madeiran waters. Courier Forschunginstitut Senckenberg, 159, 321-325.

Bourdillon-Casanova, L. (1960) Le meroplancton du Golfe de Marseille: Les larves de Crustacés Décapodes. Recuéil des Travaux de la Station Marine d'Endoume, 30(18), 1-286.

Chan, T.Y. \& Yu, H.P. (2000) A new deep-sea shrimp of the genus Plesionika Bate, 1888 (Crustacea: Decapoda: Pandalidae) from Taiwan. National Taiwan Museum Special Publication, 10, 119-127.

Clark, P.F., Calazans, D.K. \& Pohle, G.W. (1998) Accuracy and standardization of brachyuran larval descriptions. Invertebrate Reproduction and Development, 33, 127-144.

Coutière, H. (1907) Sur quelques formes larvaires enigmatiques d'Eucyphotes, provenant des collections de S. A. S le Prince de Monaco. Bulletin de l'Institut Oceanographique. Monaco, 104, 1-70.

Criales, M.M. \& Anger K. (1986) Experimental studies on the larval development of the shrimps Crangon crangon and C. allmanni. Helgöland Meeresunters, 40, 241-265.

Crosnier, A. \& Forest, J. (1973) Les crevettes profondes de l'Atlantique Oriental Tropical. Faune Tropical (ORSTOM), $19,1-409$.

dos Santos, A. (1999) Larvas de crustáceos decápodes ao largo da costa portuguesa. PhD thesis, University of Lisbon, Portugal. 285 pp.

Fransen, C.H.J.M. (2006) Pandalidae (Crustacea: Decapada) of the SONE, VALDIVIA and METEOR Expeditions 1977-1987 to the Red Sea and Gulf of Aden. Senckenbergiana maritime, 36(1), 51-82.

González, J.A. (1995) Catálogo de Crustáceos Decápodos de Las Islas Canarias. Turquesa Publisher, Santa Cruz de Tenerife, Spain. 282 pp.

González, J.A., Tuset, V.M., Lozano I.J. \& Santana J.I. (1997) Biology of Plesionika narval (Crustacea, Decapoda, Pandalidae) around the Canary Islands (Eastern Cantral Atlantic). Estuarine, Coastal and Shelf Science, 44, 339350. 
González-Gordillo, J.I., dos Santos A. \& Rodríguez A. (2001) Checklist and annotated bibliography of decapod crustacean larvae from the Southwestern European coast (Gibraltar Strait area). Scientia Marina, 65(4), $275-305$.

Gurney, R. (1924) British Antarctic "Terra Nova" Expedition, 1910. Crustacea, part IX-Decapod larvae. Natural History Report, Zoology, 8(2), 37-202.

Holthuis, L.B. (1980) FAO species catalogue. Shrimps and prawns of the world. An annotated catalogue of species of interest to fisheries. FAO Fisheries Circular, 125(1), 1-271.

Kurian, C.V. (1956) Larvae of decapod crustacea from the Adriatic Sea. Acta Adriatica, 6(3), 1-108.

Landeira, J.M., Lozano-Soldevilla, F. \& González-Gordillo, J.I. (2009) Morphology of first seven larval stages of the striped soldier shrimp, Plesionika edwardsii (Brandt, 1851) (Crustacea: Decapoda: Pandalidae) from laboratory reared material. Zootaxa, 1986, 51-66.

Lebour, M.V. (1940) The larvae of the Pandalidae. Journal of Marine Biological Association of the United Kingdom, 24, 239-252.

Pike, R.B. \& Williamson, D.I. (1964) The larvae of some species of Pandalidae (Decapoda). Crustaceana, 6, $265-284$.

Seridji, R. (1971) Contribution a l'etude des larves crustaces decapodes en baie d'Alger. Pelagos, 3, 1-105.

Thatje, S. \& Bacardit, R. (2000) Larval development of Austropandalus grayi (Cunningham, 1871) (Decapoda, Caridea, Pandalidae) from the southwestern Atlantic Ocean. Crustaceana, 73, 609-628.

Udekem D'Acoz, C.D' (1999) Inventaire et distribution des crustacés décapodes de l'Atalantique nord-oriental, de la Méditerraée et des eaux continentales adjacentes au nord de $25^{\circ}$ N. Patrimoines naturels (M.N.H.N./S.P.N.), Paris, France, 40, $383 \mathrm{pp}$.

Williamson, D.I. (1967a) Crustacea Decapoda: Larvae. IV. Caridea, Families Pandalidae and Alpheidae. Fiches d'Identification du Zooplancton, 109, 1-5.

Williamson, D.I. (1967b) On a collection of planktonic Decapoda and Stomatopoda (Crustacea) from the mediterranean coast of Israel. Bulletin of Sea Fisheries Research Station of Haifa, 45, 32-64. 